\title{
An Acheulean biface from the Deh Luran Plain, Iran
}

Mohsen Zeynivand*

In 1960, Robert Braidwood discovered, by chance, an Acheulean biface at Gakia, Kermanshah Province, in the Zagros Mountains of western Iran (Braidwood 1960). Since then, only around ten Lower Palaeolithic sites have been identified on the Iranian Plateau, most of which are open-air sites (see Biglari \& Shidrang 2006). Despite growing interest in the Palaeolithic of Iran over the past decade, studies generally continue to focus on particular sites and are largely concerned with the technology and typology of raw materials. A major problem for studies of the Lower Palaeolithic, in particular, is the rarity of cave sites, making it very difficult to study the behaviour of the early hominids through excavation. This paper reports the discovery of an Acheulean biface during a survey of the Deh Luran Plain to the south of the plateau, adding to the picture of human dispersal during the Pleistocene.

During the 1960s, Frank Hole and his team conducted a number of extensive surveys of the Deh Luran Plain, including excavations at Ali Kosh, Choqa Sefid, Faroukh Abad and Sabz (Hole et al. 1969; Wright 1981). In addition, James Neely and Henry Wright conducted a survey of ancient irrigation and canal systems, identifying around 330 artefacts, including material from a Palaeolithic site (Neely 1969). According to Neely, 96 stone artefacts were collected from an open-air site at Ain Girzan, including some with Bradostian features of the Zagros region (Neely \& Wright 1994: 163), although no photographs or drawings have been published to date.

The archaeological significance of the Deh Luran Plain lies in its strategic location between Mesopotamia and the Susiana Plain to the south, and the Central Zagros Mountains to the north (Figure 1). The plain sits between 100 and $300 \mathrm{~m}$ asl, and is situated between the Mehmeh and Dawairij Rivers. In 2016, archaeological survey in this region was undertaken in advance of new irrigation and drainage projects (Zeynivand 2016). During this work, a number of sites, from the Middle through to the Upper Palaeolithic, have been identified and studied (Figure 2). These sites are all located on the margins of the plain and on outcrops of the Bakhtiari Formation, providing abundant raw materials for lithic industries (Figure 3). A preference for similar site locations is also documented in adjacent regions such as the Karkheh Basin to the east (Bahramiyan \& Ahmadzadeh Shouhani 2016) and the Mehran Plain to the north-west (Darabi et al. 2012). One of the major discoveries during the survey of the Deh Luran Plain was an Acheulean biface, found on the northern side of Golsiri village, $8 \mathrm{~km}$ north-west of the city of Deh Luran

* Art University of Isfahan, Hakimnezami Street, Isfahan, Iran (Email: zeynivand@gmail.com) 


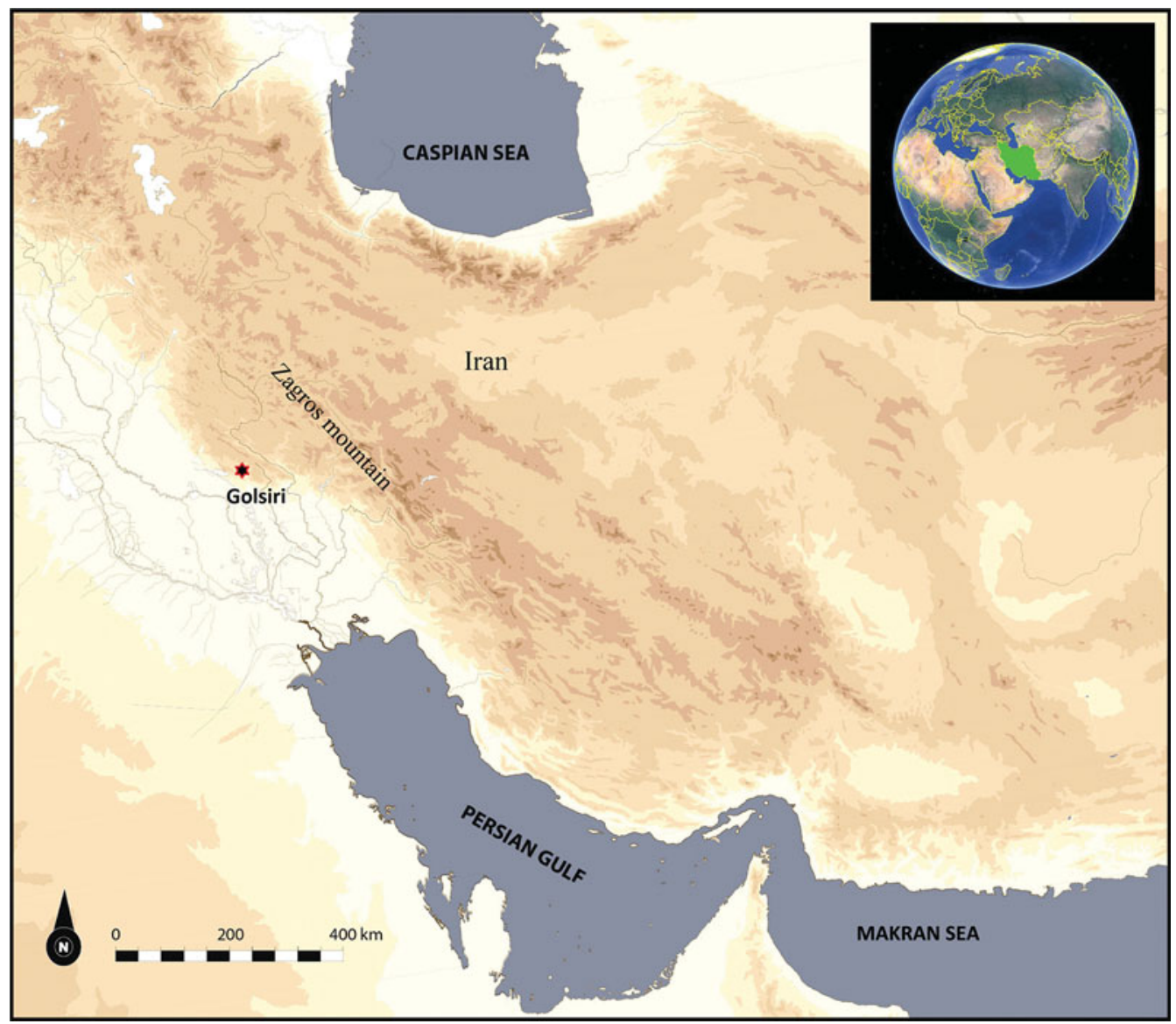

Figure 1. The location of the Golsiri site on the edge of the Central Zagros Mountains, Iran.

(Figure 4); the Mehmeh River, rising in the Kabir Kuh to the north, flows $3 \mathrm{~km}$ to the west of the site. The biface is made of chert, $23 \mathrm{~cm}$ long, $13 \mathrm{~cm}$ wide and $6 \mathrm{~cm}$ thick, and weighs $1.705 \mathrm{~kg}$ (Figure 5); a number of chips are probably due to later usage or subsequent damage.

Since its identification by Neely, Palaeolithic studies of the Deh Luran Plain have focused on the site at Ain Girzan. Neely's survey, however, omitted the north-western and western edges of the plain, and it is precisely in these areas that recent survey work has identified open-air Palaeolithic sites on the Bakhtiari Formation. These include Middle and Upper Palaeolithic sites and an Acheulean biface. In relation to the latter, the site of Amar Merdeg, $100 \mathrm{~km}$ to the north-west of Golsiri, has produced a collection of Lower Palaeolithic artefacts including a hand axe (Biglari et al. 2000). These sites are located in a natural corridor connecting the Levant with South and Central Asia, and contribute to growing knowledge of human dispersal through this region during the Pleistocene (e.g. Petraglia et al. 2009; Heydari Guran 2012; Vahdati Nasab et al. 2013).

(C) Antiquity Publications Ltd, 2017 


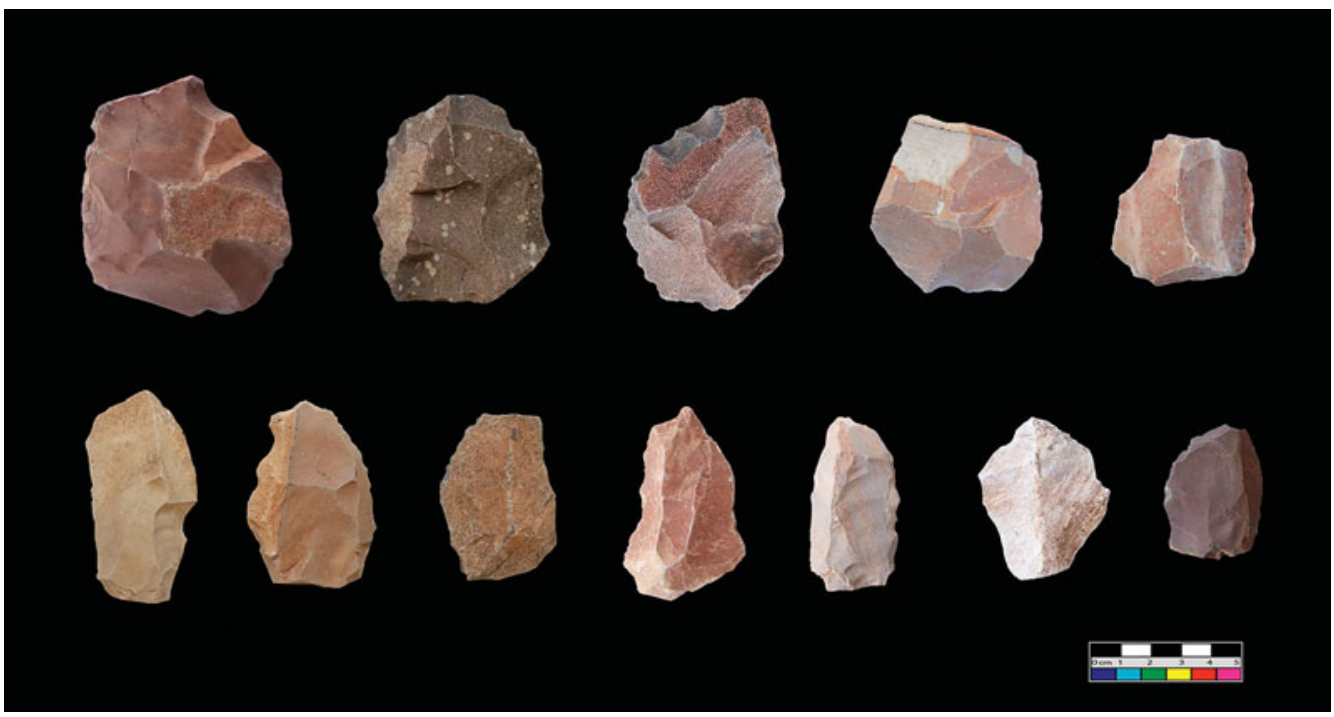

Figure 2. Some of the artefacts collected during the 2016 Deh Luran survey.

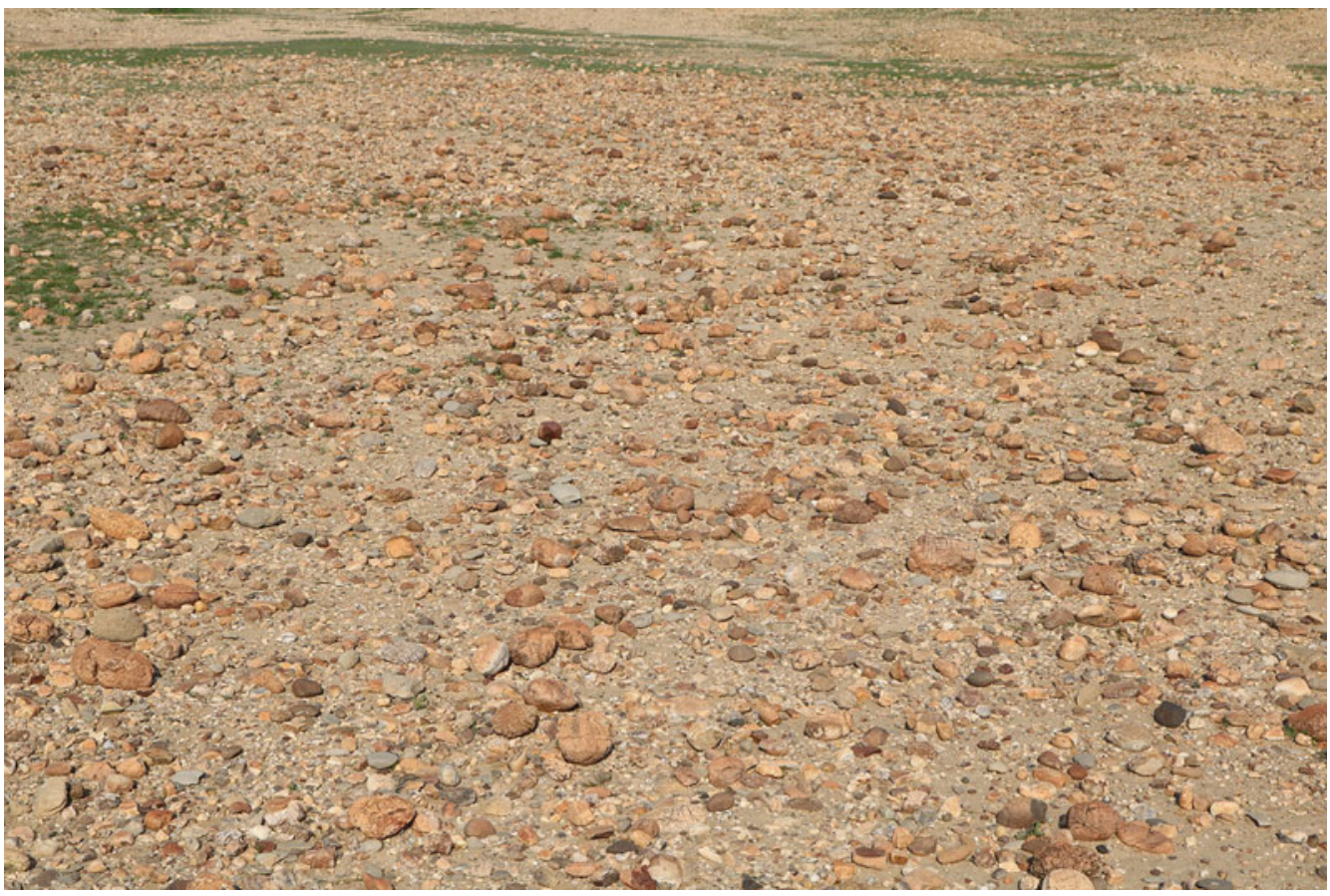

Figure 3. The availability of raw materials in Bakhtiari Formation. 


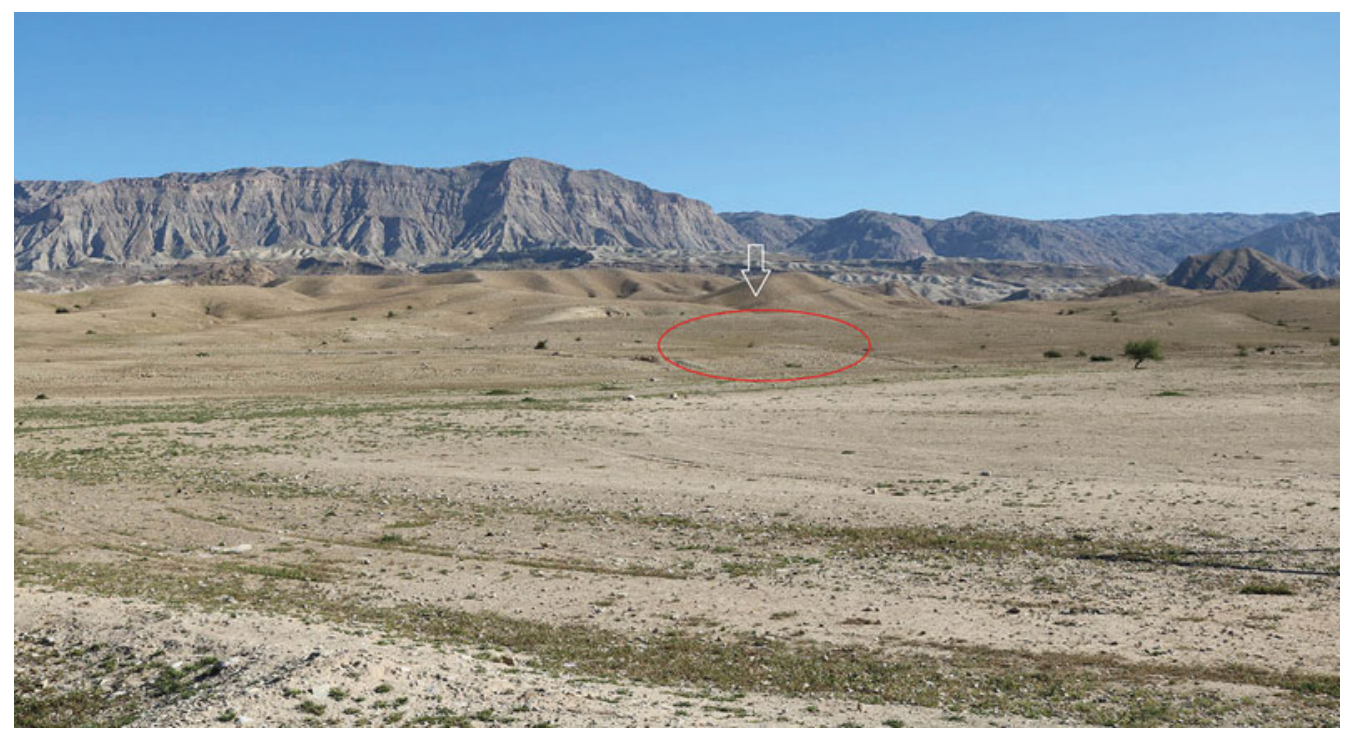

Figure 4. The landscape of the northern Deh Luran Plain and the findspot of the biface.

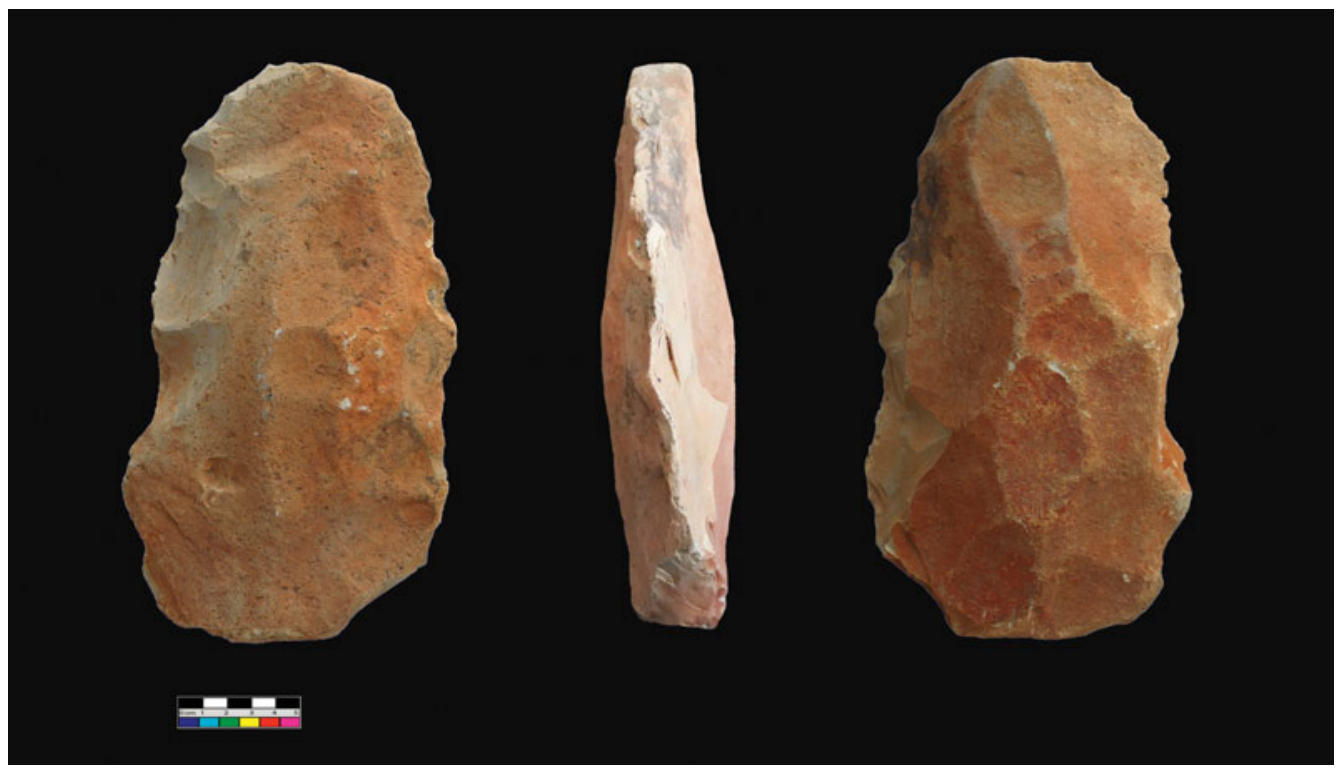

Figure 5. The Acheulean biface discovered at Golsiri.

(C) Antiquity Publications Ltd, 2017 


\section{Acknowledgements}

I would like to express my gratitude to the Iranian Center for Archeological Research, and to Siamak Sarlak especially, for issuing permission to survey and for valuable collaboration.

\section{References}

Bahramiyan, S. \& L. Ahmadzadeh Shouhani. 2016. Between mountain and plain: new evidence for the Middle Palaeolithic in the northern Susiana Plain, Khuzestan, Iran. Antiquity 90 (354): Project Gallery. http://dx.doi.org/10.15184/aqy.2016.190

Biglari, F. \& S. Shidrang. 2006. The lower Paleolithic occupation of Iran. Near Eastern Archaeology 69: 3-4, 160-68.

Biglari, F., G. Nokandeh \& S. Heydari. 2000. A recent find of a possible lower Palaeolithic assemblage from the foothills of the Zagros Mountains. Antiquity 74: 749-50. https://doi.org/10.1017/S0003598X00060257

Braidwood, R. 1960. Seeking the world's first farmers in Persian Kurdistan: a full-scale investigation of prehistoric sites near Kermanshah. The Illustrated London News 237: 695-97.

Darabi, H., A. Javanmardzadeh, A. Beshkani \& M. Jami-Alahmadi. 2012. Paleolithic occupation of the Mehran Plain in south-western Iran. Documenta Prehistorica XXXIX: 443-51. https://doi.org/10.4312/dp.39.32

Heydari Guran, S. 2012. The corridor of Iran; early modern human dispersal into the Iranian Plateau: a geographical perspective, in $\mathrm{H}$. Fahimi \& K. Alizadeh (ed.) Namvarnameh: 39-58. Tehran: Iran Negar (in Persian).

Hole, F., K. Flannery \& J. Neely. 1969. Prehistory and human ecology of the Deh Luran Plain (Memoirs of the Museum of Anthropology, University of Michigan 1). Ann Arbor: Museum of Anthropology, University of Michigan.
Neely, J. 1969. Preliminary report on the archaeological survey of the Deh Luran region, 1968-69, in Frank Hole (ed.) Preliminary reports of the Rice University project in Iran 1968-69: 9-24. Houston (TX): Rice University.

Neely, J. \& H. Wright. 1994. Early settlement and irrigation on the Deh Luran Plain; village and early state societies in southwestern Iran (Technical Report 26). Ann Arbor: Museum of Anthropology, University of Michigan.

Petraglia, M.D., N. Drake \& A. Alsharekh. 2009. Acheulean landscapes and large cutting tool assemblages in the Arabian peninsula, in M. Petraglia \& J. Rose, The evolution of human populations in Arabia; paleoenvironments, prehistory and genetics: 103-16. New York: Springer.

Vahdati Nasab, H., G.A. Clark \& S. Torkamandi. 2013. Late Pleistocene dispersal corridors across the Iranian Plateau: a case study from Mirak, a Middle Paleolithic site on the northern edge of the Iranian Central Desert (Dasht-e Kavir). Quaternary International 300: 267-81. https://doi.org/10.1016/j.quaint.2012.11.028

Wright, H. 1981. An early town on the Deh Luran Plain: excavations at Tepe Farukhabad (Memoirs of the Museum of Anthropology, University of Michigan 13). Ann Arbor: Museum of Anthropology, University of Michigan.

ZeYnivand, M. 2016. GARMSIRI Project; historical-cultural archaeology investigation, Deh Luran Plain. Report available at the Iranian Center for Archaeological Research archive (unpublished). 